\title{
Aceclofenac in Osteoarthritis - NSAID with Novel Mechanism of Action
}

\section{Dilip Shah ${ }^{1}$, Ananda K Pal ${ }^{2}$, Gurinder Bedi ${ }^{3}$, Anu Grover ${ }^{4 *}$, Amarjit Singh $^{4}$, Indranil Purkait ${ }^{4}$, Apurva Jawdekar ${ }^{4}$ and Anil Pareek ${ }^{4}$}

${ }^{1}$ Consultant Orthopedic Surgeon, Saifee Hospital, Mumbai, India

${ }^{2}$ Professor, Department of Orthopaedics and Traumatology, IPGMER, SSK Medical

College, Kolkata, West Bengal, India

${ }^{3}$ Director Orthopedics, Fortis Hospital, New Delhi, India

${ }^{4}$ Medical Affairs Department, Ipca Laboratories, Mumbai, India

*Corresponding Author: Anu Grover, Medical Affairs Department, Ipca

Laboratories, Mumbai, India.
Received: October 06, 2020

Published: November 05, 2020

(C) All rights are reserved by Anu Grover.,

et al.

\section{Abstract}

Osteoarthritis $(\mathrm{OA})$ is the most common form of arthritis, affecting millions of people worldwide. It is an inflammatory, degenerative and progressive disease which worsens over time, resulting in joint pain, swelling and stiffness. As the disease progresses, pain and stiffness become severe making daily tasks difficult, thereby affecting the quality of life. The treatment of osteoarthritis mainly focuses on management of inflammation to control the symptoms as complete reversal of the disease is not practical. Non-steroidal anti-inflammatory drugs (NSAIDs) are most commonly used and are mainstay drugs in the symptomatic treatment of osteoarthritis. Various NSAIDs are currently available in the market and looking into the co-morbidities associated with OA, there is a need for well tolerated NSAID with proven efficacy and safety. Aceclofenac, although was a late entry in crowded NSAID market, but, now is a well established drug in management of OA pain. It predominantly inhibits the inflammatory COX-2 enzyme, and due to less inhibitory action on gastroprotective COX-1 enzyme, it can be categorized as a preferential COX-2 inhibitor. Besides prostaglandin synthesis, it also inhibits synthesis of other inflammatory mediators like interleukins, tumour necrosis factor, nitric oxide and matrix metalloproteinases. This makes its efficacy similar or superior to other NSAIDs. Its efficacy has been evaluated in international studies as well as in Indian patient setting, where it has shown significant decrease in pain and severity of symptoms and improvement of functional capacity in osteoarthritis patients. Additionally, aceclofenac has a unique chondroprotective action and hence exerts a stimulatory effect on cartilage matrix synthesis. Due to preferential COX-2 inhibition, it is well-tolerated amongst the available NSAIDs, with a lower incidence of gastrointestinal and other NSAID related side effects. Good tolerability profile of aceclofenac results in decreased withdrawal rate and greater compliance of the treatment. Aceclofenac is the preferred drug for chronic therapy of osteoarthritis as long term studies highlighting the efficacy and tolerability of the drug are available. This review mainly focuses on the efficacy of aceclofenac, and also briefly mentions its safety in osteoarthritis management

Keywords: Osteoarthritis; NSAIDs; Aceclofenac; Pain; Inflammation COX Inhibitor

\section{Introduction and Overview of Osteoarthritis}

Osteoarthritis (OA) is an inflammatory, degenerative and progressive musculoskeletal disorder that mainly affects large, weight-bearing joints. Clinical characteristics include joint pain which becomes worse with activity, morning stiffness of short duration, stiffness or 'gelling' on rest and bone deformity. During OA progression, entire synovial joint, including cartilage, subchondral bones and synovium, are involved in the inflammatory process [1]. 
Evidence suggests that the progression of cartilage degradation, mediated by pro-inflammatory cytokines, contributes to tissue destruction by disrupting the balances between catabolic and anabolic activities of chondrocytes [2,3].

$\mathrm{OA}$ is an important public health problem particularly in ageing population [4]. According to World Health Organization (WHO), $18 \%$ of women and $9.6 \%$ of men aged above 60 years have symptomatic $\mathrm{OA}$, globally. One of the reference suggests that the proportion of people over the age of 60 will continue to increase and $\mathrm{OA}$ will account for more than $20 \%$ of the world's population by 2050 [5]. In rural and urban areas of India, overall prevalence of OA was found to be in the range of $21.6-39 \%$ [6-10].

$\mathrm{OA}$ is also associated with high co-morbidity rates, ranging from $37 \%$ to $73 \%$ [11,12]. In an Indian study, approximately $40.8 \%$ and $15.4 \%$ of OA patients had hypertension and diabetes mellitus, respectively at the time of the assessment [13]. This has significant ramification in the medical treatment of these people, due to the adverse effects reported with the NSAIDs. OA has become not only a serious health threat but also an economical burden to many countries [14]. The treatment goals of OA are pain-free mobilization of patients with minimal adverse effects. The mainstays of treatment are lifestyle modification, physical therapy, use of braces/splints/walking aids, oral supplementation and analgesic-anti inflammatory medication.

NSAIDs are the most commonly used drugs in the symptomatic treatment of pain as well as chronic inflammatory and degenerative joint diseases [15]. They are cornerstone in the treatment of osteoarthritis (OA) [16]. The effect of NSAIDs is mediated mainly by inhibition of prostaglandin (PG) synthesis through inhibition of cyclo-oxygenase (COX) enzyme [17]. While their efficacy has never been questioned, apprehensions have always been raised with re- gard to their safety profile because of the reported gastrointestinal (GI) and cardiovascular (CV) adverse events (AEs). The safety profile of drugs in this category, however, remains variable with marked difference amongst them [16].

Aceclofenac is a preferential COX-2 inhibitor with analgesic and anti-inflammatory properties [18]. It has shown lower incidence of GI bleeding, abdominal pain, liver toxicity, and CV events compared to traditional NSAIDs and selective COX-2 inhibitors [17]. Additionally, studies have also demonstrated that aceclofenac can stimulate glycosaminoglycans (GAGs) synthesis which is an important constituent of normal cartilage [19-21]. In the current review, we have gathered information on the clinical evidence of aceclofenac in OA. The studies included are both from worldwide experience and Indian patient setting.

\section{Treatment of OA - Focus on NSAIDs}

As mentioned earlier, OA has primarily a degenerative component with added inflammatory component. Full reversal of the disease is not a practical solution hence management of inflammation to control the symptoms is part of the treatment algorithm. The symptom management relies on the combination of non-pharmacological and pharmacological approaches that are generally tailored to the patient's needs and risk factors [22]. Paracetamol, NSAIDs, opioid analgesics, and various topical therapies have been found to be efficacious in the treatment of OA pain. The clinical efficacy of oral NSAIDs is well established and they also lack the addictive potential of opioids [23]. They are the cornerstone in treatment of OA [16]. Several guidelines have also recommended the use of oral NSAIDs in patients with persistent symptoms that have not responded adequately to paracetamol with or without topical NSAIDs (Table 1).

\begin{tabular}{|c|c|}
\hline Guideline & Recommendations \\
\hline ESCEO-2016 [24] & Oral NSAIDs play a central role in the advanced pharmacological treatment of knee OA \\
\hline OARSI-2019 [25] & $\begin{array}{l}\text { NSAIDs with favourable safety profiles may be used at the lowest possible dose, for the } \\
\text { shortest possible treatment duration. }\end{array}$ \\
\hline NICE-2014 [26] & $\begin{array}{l}\text { Substitution with an oral NSAID should be considered when paracetamol or topical NSAIDs } \\
\text { are ineffective for pain relief for people with OA } \\
\text { Use oral NSAID at the lowest effective dose for the shortest possible period of time }\end{array}$ \\
\hline ACR-2012 [27] & NSAIDs are recommended for the initial treatment of patients with hip, knee and hand OA \\
\hline RACGP-2018 [28] & $\begin{array}{l}\text { NSAIDs taken orally at low doses for short periods are recommended for some people with } \\
\text { knee and/or hip OA }\end{array}$ \\
\hline $\begin{array}{l}\text { EULAR-2018 } \\
\text { [29] }\end{array}$ & In hand OA, oral NSAIDs effectively improves pain and function \\
\hline EMEA -2010 [30] & NSAIDs should be used for OA and OA flare up pain \\
\hline \multicolumn{2}{|c|}{$\begin{array}{l}\text { ACR, American College of Rheumatology; OARSI, Osteoarthritis Research Society International; NICE, National } \\
\text { Institute for Health and Care Excellence; ESCEO European Society for Clinical and Economic Aspects of Osteo- } \\
\text { porosis, Osteoarthritis and Musculoskeletal Diseases; RACGP, Royal Australian College of General Practitioners; } \\
\text { EULAR, European League Against Rheumatism; EMA, European Medicines Agency. }\end{array}$} \\
\hline
\end{tabular}

Table 1: Guidelines recommendations for the use of NSAIDs in knee OA. 
Over the past few years, widespread use of oral NSAIDs has been questioned due to significant upper GI complications and CV AEs. However, NSAIDs are non-homogeneous, and there are noticeable differences between them in AE risk for GI and CV events [16]. NSAIDs work by inhibiting cyclo-oxygenase (COX), a key enzyme of PG biosynthesis. It exists in two isoforms: COX-1 and COX-2, the constitutive and inducible form, respectively. COX-1 catalyzes formation of cytoprotective PGs in thrombocytes, stomach mucosa, kidneys, vascular endothelium, pancreas, seminal vesicles, Langerhans islets and brain. Induction of COX-2 by various growth factors, endotoxins, mitogens, pro-inflammatory agents and tumor agents indicates its role in initiation of pathological processes, like inflammation. Efficacy of NSAIDs mainly depend on the inhibition of COX-2 enzyme, whereas the toxic effects like GI, platelet and renal effects are mostly due to the inhibition of COX-1 enzyme. Higher potency of NSAIDs against COX-2 and an improved COX-2/ COX-1 ratio will have anti-inflammatory activity along with fewer GI side effects. Non-selective NSAIDs may have higher potency against COX-1 compared to COX-2 and therefore cause higher GI toxicity [31].

Development of COXIBS (celecoxib, rofecoxib, and valdecoxib), designed to inhibit selectively COX-2 enzyme, was based on the hypothesis that COX-2 is the source of $\mathrm{PGE}_{2}$, which mediate inflammation. However, on September 30, 2004, rofecoxib was withdrawn from the market due to an increased risk of myocardial infarction compared with placebo [32] and on December 9, 2004, the FDA issued a black-box warning for the selective COX-2 inhibitor, valdecoxib for life-threatening skin reactions and increased CV risk. This drug was later withdrawn by the manufacturer [33].

Currently, number of NSAIDs are available commercially; they are classified in table 2. Choosing an appropriate NSAID might be difficult, thus some important criteria for selecting and using NSAIDs in primary health care are mentioned in table $3[18,34,35]$.

\section{Aceclofenac: An effective NSAID}

Development of NSAID with a goal of improved efficacy and lower incidences of side effects resulted in the introduction of aceclofenac. It is one of the most commonly prescribed NSAID for patients with OA in Indian and European population [18,36]. Its efficacy has been found to be superior or at least comparable to other NSAIDs such as diclofenac, piroxicam, naproxen, ibuprofen and etoricoxib [37-43]. Aceclofenac is well tolerated with a lower incidence of GI and CV adverse effects, which results in lesser withdrawal rate and greater compliance with the treatment $[15,18,44,45]$.

\begin{tabular}{|l|c|}
\hline Class & Drugs \\
\hline Salicylic acid derivative & Aspirin, Sodium salicylate \\
\hline $\begin{array}{l}\text { Para-aminophenol } \\
\text { derivative }\end{array}$ & Acetaminophen \\
\hline Acetic acid derivative & $\begin{array}{c}\text { Indomethacin, sulindac, etodolac, } \\
\text { diclofenac, ketorolac, Aceclofenac }\end{array}$ \\
\hline Arylpropionic acids & $\begin{array}{c}\text { Ibuprofen, naproxen, ketoprofen, } \\
\text { flurbiprofen acid }\end{array}$ \\
\hline Anthranilic acid & Mefenamic acid \\
\hline Enolic acid & Piroxicam, meloxicam \\
\hline Alkenones & Nabumetone \\
\hline Sulfonilides & Nimesulide \\
\hline Coxib & Celecoxib, etoricoxib \\
\hline
\end{tabular}

Table 2: Classification of non-steroidal analgesics.

\begin{tabular}{|l|c|}
\hline $\begin{array}{l}\text { Patient } \\
\text { profile }\end{array}$ & $\begin{array}{c}\text { Age of patient: especially extremes of age are } \\
\text { important }\end{array}$ \\
& $\begin{array}{c}\text { General condition of the patient } \\
\text { Co-morbid condition: drug-drug interaction has } \\
\text { to be kept in mind in such patients }\end{array}$ \\
\hline Pain history & $\begin{array}{c}\text { Site of the pain (this may indicate an underlying } \\
\text { local cause or a referred origin) } \\
\text { Nature of the pain (duration, speed of onset, } \\
\text { whether pain is intermittent or constant) } \\
\text { Origin of the pain (Neuropathic, somatic, vis- } \\
\text { ceral) }\end{array}$ \\
\hline Efficacy & $\begin{array}{c}\text { Severity of the pain (Mild or moderate or } \\
\text { severe) }\end{array}$ \\
\hline Safety & pyretic action, onset of duration of action \\
\hline
\end{tabular}

Table 3: Key factors for selection of NSAIDs.

Pharmacokinetics of aceclofenac

The pharmacokinetic properties of aceclofenac have been studied after oral administration of single or multiple doses to young and elderly healthy volunteers and multiple doses to patients with acute knee arthroses (Table 4).

\section{Pharmacodynamics of aceclofenac}

\section{Preferential COX-2 inhibition}

Being NSAID, aceclofenac acts on COX pathway, which plays a key role in reduction of pain and inflammation. In long-term invitro assays, maximal plasma levels of diclofenac following oral 
administration of aceclofenac (0.39 mol/L) or diclofenac $(1.28$ mol/L) were sufficient for larger than $97 \%$ inhibition of COX-2 (50\% inhibitory concentration, $0.024 \mathrm{~mol} / \mathrm{L}$ ) and a $46 \%$ (aceclofenac treatment) or $82 \%$ inhibition (diclofenac treatment) of COX-1 (50\% inhibitory concentration, $0.43 \mathrm{~mol} / \mathrm{L}$ ) [50] (Figure 1). Aceclofenac decreases PGE2 production not only by direct inhibition of COX-2 activity, but also by down-regulating COX-2 synthesis in the cartilage [51]. Evidence of its COX-2 selectivity has been shown by an IC50 ratio (COX-2: COX-1) of 0.26, which falls between IC50 ratios of 0.12 and 0.7 for the COX-2 inhibitors rofecoxib and celecoxib, respectively [49].

\begin{tabular}{|l|c|}
\hline \multirow{2}{*}{ Absorption } & $\begin{array}{c}\text { Orally, rapidly and completely absorbed } \\
\text { Peak plasma levels reached after 1.25 } \\
\text { to 3 hours }\end{array}$ \\
\hline Distribution & $\begin{array}{c}\text { Volume of distribution is about 25 L } \\
\text { High (>99\%) protein-binding }\end{array}$ \\
\hline Metabolism & $\begin{array}{c}\text { Metabolized via CYP2C9 to the main } \\
\text { metabolite 4-hydroxyaceclofenac }\end{array}$ \\
& $\begin{array}{c}\text { Approx. 5\% other minor metabolites } \\
\text { include 5-hydroxyaceclofenac, di- } \\
\text { clofenac, 5-hydroxydiclofenac and 4-hy- } \\
\text { droxy diclofenac }\end{array}$ \\
\hline Excretion & $\begin{array}{c}\text { 70 to 80\% of an administered dose } \\
\text { found in the urine, mainly as the } \\
\text { glucuronides of aceclofenac and its } \\
\text { metabolites and 20\% is excreted in the } \\
\text { faeces. }\end{array}$ \\
& $\begin{array}{r}\text { Plasma elimination half-life is approx. } \\
\text { 4 hours }\end{array}$ \\
\hline
\end{tabular}

Table 4: Pharmacokinetic parameters of Aceclofenac [46-49].

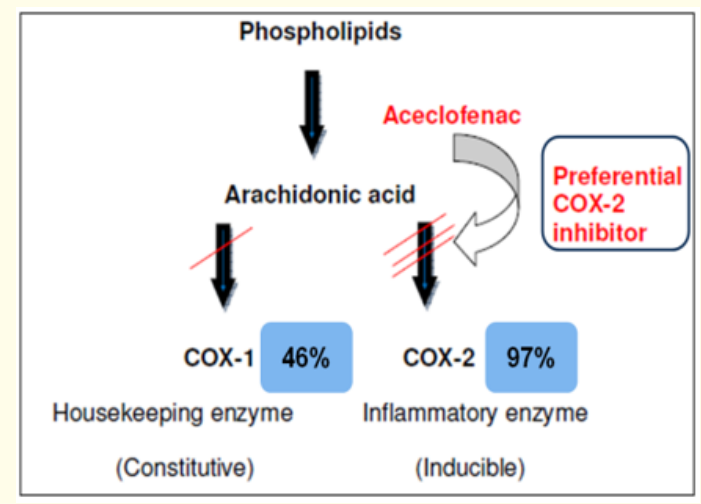

Figure 1: Mechanism of action of aceclofenac.
Effect on inflammatory mediators

In-vitro studies have revealed that aceclofenac inhibits several mediators of inflammation like interleukin (IL)-1, IL-6, nitric oxide (NO), matrix metalloproteases (MMP), and tumor necrosis factor (TNF) [52-55].

Effect on IL-1 and IL-1 receptor antagonist (IL-1Ra): IL-1 is a pro-inflammatory cytokine that plays an important role in articular inflammation and cartilage degradation. It increases the synthesis of several inflammatory mediators such as $\mathrm{NO}, \mathrm{PGE}_{2}$, free oxygen radicals, MMP, and other cytokines. IL-1Ra inhibits the biological action of IL-1. When IL-1Ra binds to the IL-1 receptor on chondrocytes, the induction of $\mathrm{PGE}_{2}$ and tissue degrading enzymes by these cells are prevented [56]. An in-vitro study has demonstrated that aceclofenac, at therapeutic concentration, markedly inhibited IL-1 $\alpha$ and IL-1 $\beta$ involved in OA pathophysiology [53]. It may also modulate $\mathrm{PGE}_{2}$ production by increasing IL-1Ra production in human articular chondrocytes [54].

Effect on IL-6: IL-6 acts as both a pro-inflammatory and antiinflammatory cytokine. Aceclofenac significantly inhibited IL-6 production in OA chondrocytes culture [52].

Effect on TNF- $\alpha$ : The TNF- $\alpha$ level, like IL-1 $\beta$, was markedly increased (by 12 times) when the synovial explants were treated with lipopolysaccharide (LPS). Aceclofenac significantly inhibited LPSstimulated TNF- $\alpha$ synthesis at all dosages tested [53].

Effect on NO: OA chondrocytes produce a larger amount of NO under pro-inflammatory cytokine stimulated conditions, such as with IL-1ß or TNF- $\alpha$. Excessive concentration of NO exert profound effects on chondrocytes functions, including down regulation of collagen synthesis, chondrocytes proliferation, inhibition of actin polymerization, down regulation of IL-1Ra expression, activation of metalloproteases and induction of apoptosis. Aceclofenac inhibited the NO production induced by IL-1ß by $40 \%$ to $70 \%$ in human OA chondrocytes [54].

Effect on MMP: In a study, 4-hydroxy aceclofenac, one of the major metabolites of aceclofenac, reduced both basal and IL-1 $\beta$ induced production of proMMP-1 and proMMP-3 at a concentration adequate to suppress $\mathrm{PGE}_{2}$ production [55].

Effective reduction of PG: Under basal conditions, $\mathrm{PGE}_{2}$ production was significantly higher in $\mathrm{OA}$ than in normal chondrocyte cultures. Upon IL-1 $\beta(5 \mathrm{U} / \mathrm{ml})$ stimulation, $\mathrm{PGE}_{2}$ amounts produced by normal and OA chondrocytes were enhanced by 2 and 6 times, 
respectively. Aceclofenac decreased in a dose-dependent manner both basal and IL-1 $\beta$-stimulated $\mathrm{PGE}_{2}$ production [52]. In addition, in a clinical study, $\mathrm{PGE}_{2}$ level in the synovial fluid reduced significantly with aceclofenac (113 to $66.8 \mathrm{pg} / \mathrm{ml}$ ) compared to diclofenac (127.5 to $101.3 \mathrm{pg} / \mathrm{ml}$ ) [56].

Effect on L-selectin and neutrophil adhesion: L-selectin is a highly glycosylated protein constitutively expressed by neutrophils. It is involved in the rolling of neutrophils on activated endothelium, a process that causes firm adhesion and extravasation of the neutrophils. In an in-vitro study, aceclofenac significantly reduced the L-selectin dependent neutrophils adhesion to endothelial cells [57].
Chondroprotective action of aceclofenac

Human articular cartilage is continually remodelled during adult life [19]. In OA, cartilage synthetic activity is reduced by almost $50 \%$ as compared with normal cartilage [20]. Aceclofenac has stimulatory effect on matrix synthesis; Stimulatory effect of aceclofenac on human glycosaminoglycan (GAG) synthesis may be ascribed to the inhibition of IL-1 activity, thus allowing the expression of indigenous growth factor activity [19-21]. Aceclofenac increased the synthesis of proteoglycans and Hyaluronic acid in explants with mild $\mathrm{OA}$ and severe $\mathrm{OA}$, in a dose-dependent manner. In multiple studies on cartilage protection, aceclofenac showed unique characteristic of being chondroprotective (Table 5 and 6).

\begin{tabular}{|l|c|c|c|}
\hline \multicolumn{2}{|c|}{$\begin{array}{c}\text { Effect on matrix synthesis [20] } \\
\text { (UK Experience) }\end{array}$} & \multicolumn{2}{c|}{$\begin{array}{c}\text { Effect on GAG synthesis [58] } \\
\text { (Canadian Experience) }\end{array}$} \\
\hline Aceclofenac & Stimulatory effect & Aceclofenac & Stimulatory effect \\
\hline Piroxicam Aspirin & No significant effect & Diclofenac Aspirin Piroxicam & Neutral effect \\
\hline $\begin{array}{l}\text { Indomethacin } \\
\text { Naproxen } \\
\begin{array}{l}\text { Ibuprofen } \\
\text { Nimesulide }\end{array}\end{array}$ & Significant inhibitory effect & Indomethacin Naproxen & Inhibitory effect \\
\hline
\end{tabular}

Table 5: Effect of NSAIDs on cartilage GAG synthesi.

\begin{tabular}{|l|l|}
\hline $\begin{array}{l}\text { Inhibits cartilage } \\
\text { degradation }\end{array}$ & $\begin{array}{c}\text { Increases cartilage } \\
\text { synthesis }\end{array}$ \\
\hline Decreases IL-1 & \\
Decreases NO & $\begin{array}{c}\text { Increases proteoglycans } \\
\text { Increases hyaluronic acid }\end{array}$ \\
Increases IL-1Ra & \\
\hline
\end{tabular}

Table 6: Chondroprotective action of aceclofenac [21,54,55,59].

\section{Efficacy of aceclofenac in osteoarthritis}

Various clinical studies have shown that aceclofenac reduces pain score, severity of symptoms and improves the functional capacity of the affected joints in OA patients. Efficacy of aceclofenac is found to be superior or equivalent to other commonly used NSAIDs in OA.

\section{Worldwide experience of aceclofenac in OA (Table 7)}

In a multicentre randomised study conducted in UK and Belgium, Ward DE., et al. observed that 74.5 and $70.4 \%$ patients in the aceclofenac and diclofenac group had an improvement in pain intensity. Additionally, knee flexion improvement was significantly more effective in aceclofenac group than diclofenac group patients after 2-4 weeks of treatment. At the end point, 71\% patients reported improvement in pain intensity as compared to $59 \%$ patients treated with diclofenac [37].

Two trials were conducted in Spain, in comparison to naproxen and piroxicam [38,40]. After 15 days of treatment, aceclofenac demonstrated rapid improvement in knee flexion in comparison to piroxicam. Knee flexion measurement were increased by $11.48^{0}$ from baseline in aceclofenac group compared to $8.46^{\circ}$ in piroxicam group ( $p=0.376$ ) (Figure 2) [38]. In another study conducted in Spain, improvement in OA symptoms is documented in $73 \%$ patients treated with aceclofenac vis-a vis $68.5 \%$ of the patients treated with naproxen [40].

\section{Indian experience of aceclofenac in $\mathrm{OA}$}

Number of clinical trials has been done to analyse the comparative efficacy of Aceclofenac with other NSAIDs such as diclofenac, etoricoxib and ibuprofen in Indian patients suffering from OA (Table 8). 


\begin{tabular}{|c|c|c|c|c|c|c|}
\hline $\begin{array}{l}\text { Author and } \\
\text { Year }\end{array}$ & Country & Study type & Intervention & $\begin{array}{l}\text { Number } \\
\text { and age } \\
\text { of partici- } \\
\text { pants* }\end{array}$ & $\begin{array}{l}\text { Duration } \\
\text { of study }\end{array}$ & Pain and Physical function assessment \\
\hline $\begin{array}{l}\text { Torri., et al. } \\
1994 \text { [39] }\end{array}$ & Spain & $\begin{array}{l}\text { Randomized, } \\
\text { double-blind, } \\
\text { controlled } \\
\text { study }\end{array}$ & $\begin{array}{c}\text { Aceclofenac } \\
(100 \mathrm{mg} \text { bid; } \\
\mathrm{n}=103) \text { vs. } \\
\text { piroxicam }(20 \\
\text { mg od; } \mathrm{n}=102)\end{array}$ & $\begin{array}{c}205 \\
18-75 \text { years }\end{array}$ & 3 months & $\begin{array}{l}\text { VAS: At end point, similar improvement } \\
\text { in both the group (35.7 mm, Aceclofenac } \\
\text { vs. } 38.5 \mathrm{~mm} \text { piroxicam) } \\
\text { Knee flexion: At end point, improved by } \\
10^{\circ} \text { in aceclofenac vs. } 9^{\circ} \text { in } \\
\text { piroxicam group }\end{array}$ \\
\hline $\begin{array}{l}\text { Ward., et al. } \\
1995 \text { [37] }\end{array}$ & $\begin{array}{l}\text { UK and } \\
\text { Belgium }\end{array}$ & $\begin{array}{l}\text { Multicentre } \\
\text { randomised, } \\
\text { double-blind } \\
\text { study }\end{array}$ & $\begin{array}{l}\text { Aceclofenac } \\
(100 \mathrm{mg} \text { bid; } \mathrm{n} \\
=200) \mathrm{vs} \text {. Di- } \\
\text { clofenac (50 mg } \\
\text { tid; } \mathrm{n}=197)\end{array}$ & $\begin{array}{c}397 \\
18-75 \text { years }\end{array}$ & 12 weeks & $\begin{array}{l}\text { 5-point scale: Significant improvement } \\
\text { in pain intensity in both groups ( } 74.5 \% \text {, } \\
\text { aceclofenac vs. } 70.4 \% \text {, diclofenac) } \\
\text { Knee flexion: At endpoint, improvement } \\
\text { is better with aceclofenac }\left(10^{\circ}\right) \text { vs. diclof- } \\
\text { enac }\left(5^{\circ}\right)\end{array}$ \\
\hline $\begin{array}{l}\text { Busquier., } \\
\text { et al. } \\
1997 \text { [38] }\end{array}$ & Spain & $\begin{array}{l}\text { A multicentre, } \\
\text { double-blind, } \\
\text { randomised } \\
\text { study }\end{array}$ & $\begin{array}{c}\text { Aceclofenac } \\
(100 \text { mg bid; } \\
n=123) \text { vs. } \\
\text { Piroxicam ( } 20 \\
\text { mg od; } n=117)\end{array}$ & $\begin{array}{c}240 \\
40-80 \text { years }\end{array}$ & 2 months & $\begin{array}{l}\text { VAS: At end point, similar improvement } \\
\text { in both the groups ( } 33.8 \mathrm{~mm} \text {, aceclofenac } \\
\text { vs. } 34.8 \mathrm{~mm} \text {, piroxicam) OSI: Similar } \\
\text { improvement in both the groups in all } \\
\text { time points } \\
\text { Knee flexion: At end point, improved by } \\
11.48^{\circ} \text { in aceclofenac vs. } 8.46^{\circ} \text { in } \\
\text { piroxicam group }\end{array}$ \\
\hline $\begin{array}{l}\text { Kornasoff., } \\
\text { et al. } 1997 \\
{[40]}\end{array}$ & Spain & $\begin{array}{l}\text { Multi-centre, } \\
\text { twelve-week, } \\
\text { randomized, } \\
\text { double-blind, } \\
\text { parallel- }\end{array}$ & $\begin{array}{l}\text { Aceclofenac } \\
(100 \text { mg bid; } \\
\text { n = 190) vs. } \\
\text { naproxen } \\
\text { (500 mg bid; } n \\
\quad=184)\end{array}$ & $\begin{array}{c}382 \\
18-75 \text { years }\end{array}$ & 12 weeks & $\begin{array}{l}\text { 5-point scale: Significant improvement in } \\
\text { pain on movement with aceclofenac and } \\
\text { naproxen groups ( } 83.4 \% \text { vs. } 86.1 \%) \text {; and } \\
\text { pain on rest ( } 76.2 \% \text { vs. } 81.8 \%) \\
\\
\text { Knee flexion: At end point, significantly } \\
\text { improved by } 13.8^{\circ} \text { in both aceclofenac } \\
\text { and piroxicam group }\end{array}$ \\
\hline
\end{tabular}

Table 7: Worldwide experience of Aceclofenac in patients with knee OA.

\begin{tabular}{|c|c|c|c|c|c|}
\hline $\begin{array}{c}\text { Author and } \\
\text { Year }\end{array}$ & Study type & Intervention & $\begin{array}{c}\text { Number and age } \\
\text { of participants* }\end{array}$ & $\begin{array}{c}\text { Duration } \\
\text { of study }\end{array}$ & Pain and physical assessment \\
\hline Pareek., et al. & $\begin{array}{c}\text { Controlled, } \\
\text { comparative, } \\
\text { randomized, } \\
\text { and double- } \\
\text { blind }\end{array}$ & $\begin{array}{c}\text { Aceclofenac (100 } \\
\text { mg bid; } \mathrm{n}=125) \mathrm{vs} \\
\text { diclofenac }(75 \mathrm{mg} \\
\text { bid; } \mathrm{n} \text { 122) }\end{array}$ & $40-82$ years & 8 weeks & $\begin{array}{c}\text { VAS: At end point, similar improvement in } \\
\text { both the group WOMAC score: At the end } \\
\text { point, significant improvement in aceclof- } \\
\text { enac vs. diclofenac group (23.2 vs. 16.8) }\end{array}$ \\
\hline Pareek., et al. & $\begin{array}{c}\text { Open, ran- } \\
\text { domized and } \\
\text { comparative } \\
\text { study }\end{array}$ & $\begin{array}{c}\text { Aceclofenac (100 } \\
\mathrm{mg} / \text { paracetamol } \\
500 \mathrm{mg} \text { bid } \mathrm{n}=101) \\
\text { vs. aceclofenac (100 } \\
\mathrm{mg} \text { bid; } \mathrm{n}=98)\end{array}$ & $40-70$ years & 10 day & $\begin{array}{c}\text { PID: Combination was superior to mono- } \\
\text { therapy at all time points SPID: Combina- } \\
\text { tion was superior (5.46 vs. 3.63) Peak PID: } \\
\text { Combination was superior (2.08 vs. 1.56) } \\
\text { WOMAC score: At the end point, similar } \\
\text { improvement in both group (16 vs. 18) }\end{array}$ \\
\hline
\end{tabular}




\begin{tabular}{|c|c|c|c|c|c|}
\hline $\begin{array}{l}\text { Pareek., et al. } \\
\text { 2011[62] }\end{array}$ & $\begin{array}{l}\text { Comparative, } \\
\text { Randomized, } \\
\text { Multicentric, } \\
\text { Double-Blind } \\
\quad \text { Study } \\
\end{array}$ & $\begin{array}{l}\text { Aceclofenac-CR ( } \\
=143 ; 200 \mathrm{mg} \text { OD) } \\
\text { and aceclofenac ( } \mathrm{n}= \\
\text { 132; } 100 \mathrm{mg} \text { bid) }\end{array}$ & $\begin{array}{c}285 \\
40-65 \text { years }\end{array}$ & 6 week & $\begin{array}{l}\text { VAS: At end point similar improvement in } \\
\text { pain intensity in both groups ( } 3.2 \mathrm{vs.} 3.2 \text { ) } \\
\text { WOMAC score: At end point similar im- } \\
\text { provement in both groups ( } 23.6 \mathrm{vs} .24 .6 \text { ) }\end{array}$ \\
\hline $\begin{array}{l}\text { Reddy., et al. } \\
2012 \text { [60] }\end{array}$ & $\begin{array}{l}\text { Randomized, } \\
\text { single blinded, } \\
\text { parallel group } \\
\text { clinical study }\end{array}$ & $\begin{array}{l}\text { Aceclofenac ( } \mathrm{n}= \\
70 ; 100 \mathrm{mg} \text { bid) vs. } \\
\text { diclofenac ( } \mathrm{n}=70 ; \\
75 \mathrm{mg} \text { bid) }\end{array}$ & $\begin{array}{c}140 \\
40-60 \text { years }\end{array}$ & 8 weeks & $\begin{array}{l}\text { VAS: At end point similar improvement in } \\
\text { aceclofenac vs. diclofenac treated patients } \\
(2.33 \text { vs.1.75) WOMAC score: At end point } \\
\text { superior improvement in aceclofenac vs. } \\
\text { diclofenac treated patients (18.8 vs.13.8) }\end{array}$ \\
\hline $\begin{array}{l}\text { Ali., et al. } \\
2017 \text { [61] }\end{array}$ & $\begin{array}{l}\text { Prospective, } \\
\text { observational } \\
\text { study }\end{array}$ & $\begin{array}{l}\text { Aceclofenac }(\mathrm{n}= \\
\text { 90) vs. diclofenac ( } \mathrm{n} \\
=25)\end{array}$ & $\begin{array}{c}115 \\
\geq 40 \text { years }\end{array}$ & 6 months & $\begin{array}{l}\text { WOMAC score: At end point similar im- } \\
\text { provement in aceclofenac vs. diclofenac } \\
\text { treated patients ( } 36.4 \text { vs. } 34.4 \text { ) }\end{array}$ \\
\hline $\begin{array}{l}\text { Klair., et al. } \\
2009[43]\end{array}$ & $\begin{array}{l}\text { Comparative } \\
\text { study }\end{array}$ & $\begin{array}{l}\text { Aceclofenac ( } \mathrm{n}= \\
\text { 25; } 100 \mathrm{mg} \text { bid) vs. } \\
\text { Ibuprofen }(\mathrm{n}=25 \\
\quad 400 \mathrm{mg} \text { tid.) }\end{array}$ & $\begin{array}{c}50 \\
30-75 \text { years }\end{array}$ & 6 week & $\begin{array}{l}\text { VAS: is significantly reduced with aceclof- } \\
\text { enac vs. ibuprofen ( } 36.6 \text { vs. } 20.2 \text { ) }\end{array}$ \\
\hline $\begin{array}{l}\text { Waraich., et } \\
\text { al.2018 [42] }\end{array}$ & $\begin{array}{l}\text { Prospective, } \\
\text { open label, in- } \\
\text { tention to treat } \\
\text { study }\end{array}$ & $\begin{array}{l}\text { Etoricoxib } 30 \mathrm{mg} \\
\text { od) vs. Aceclofenac } \\
\text { (100mg bid) }\end{array}$ & $\begin{array}{c}80 \\
35-60 \text { years }\end{array}$ & 6 week & $\begin{array}{l}\text { VAS: At end point, significant improvement } \\
\text { in aceclofenac vs. etoricoxib ( } 71 \mathrm{~mm} \text { vs. } \\
53 \mathrm{~mm} \text { ) WOMAC: At end point, superior } \\
\text { improvement in etoricoxib vs. aceclofenac } \\
\text { treated patients ( } 56.4 \text { vs. } 40 \text { ) }\end{array}$ \\
\hline
\end{tabular}

Table 8: Efficacy of aceclofenac in comparison with other NSAIDs in Indian patients with knee OA.

* All the studies mentioned included both male and female participants.
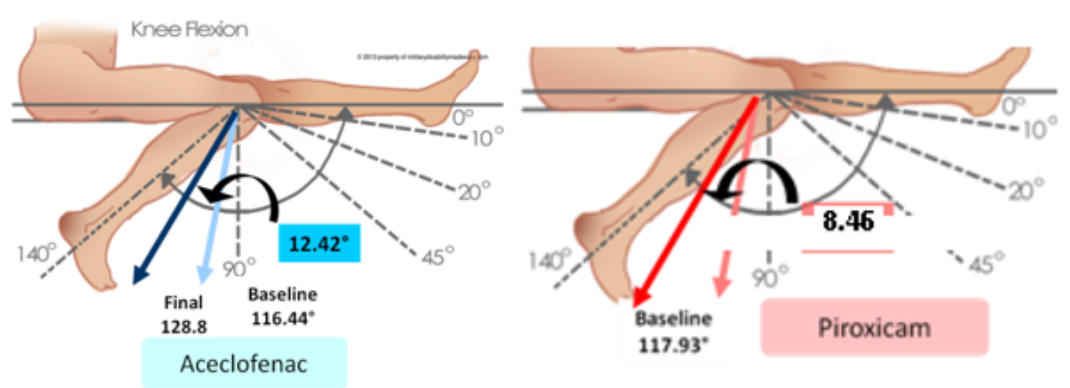

Figure 2: Effect of aceclofenac on knee flexion.

In a study by Pareek., et al. aceclofenac was found to be as effective as diclofenac in the treatment of OA. Nevertheless, in some efficacy parameters: Western Ontario Macmaster (WOMAC), joint tenderness, and investigator's assessment (disease status and response to therapy), aceclofenac was found to be statistically superior to diclofenac [18]. The overall clinical response to aceclofenac was proved to be statistically better than diclofenac, as reported by both patient and physician scored outcomes [18]. In another study, aceclofenac-paracetamol fixed dose combination was proved to be effective in alleviating OA flare-up pain. Aceclofenac, both in combination and as monotherapy is comparable in efficacy with reference to changes in WOMAC scores, average pain intensity and resolution of baseline signs and symptoms of OA flare-up like morning stiffness, swelling and nocturnal pain [41]. 
Reddy., et al. demonstrated the superiority of aceclofenac to diclofenac in the improvement of WOMAC scores (18.8 vs. 13.8). Additionally, improvement in joint tenderness, investigator assessment for disease status $(p=0.01)$ and response to therapy $(p=$ $0.038)$, patient response to drug $(p=0.024)$ were also superior for aceclofenac vs. diclofenac treated patients [60]. In the investigator's judgment, $90 \%$ patients from aceclofenac group and $80 \%$ patients in the diclofenac group experienced high to moderate response to the therapy [61].

In comparison to Ibuprofen, pain on Visual Analogue Scale (VAS) is significantly reduced with aceclofenac vs. ibuprofen (36.6 vs. 20.2) after 6 weeks of treatment in OA (Figure 3). Also, higher percentage of patients in the aceclofenac group showed improvement in pain intensity (76 vs. 64\%), pain on movement (72 vs. $60 \%$ ), joint tenderness (72 vs. 60\%), swelling (60 vs. 44\%), erythema ( 24 vs. 12\%), functional capacity (72 vs. 60\%) and overall assessment (72 vs. 60\%) [43].

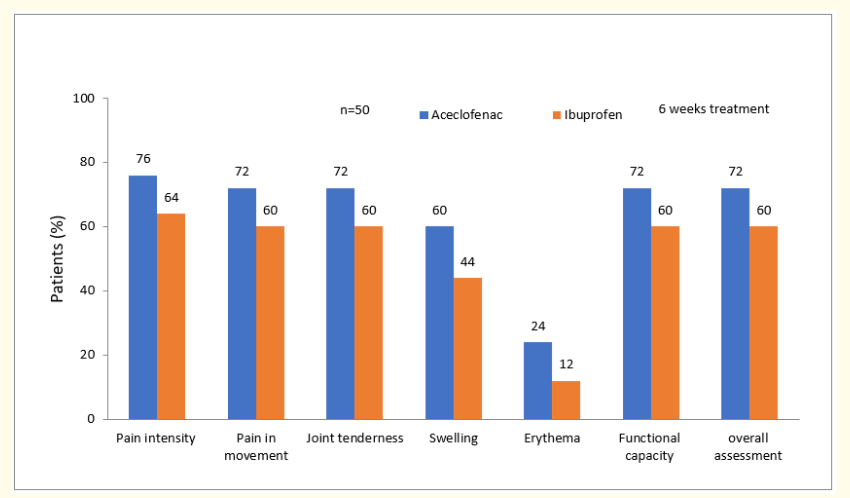

Figure 3: Improvement in functional status in different parameters.

In a short term, comparative study, aceclofenac was also proved to be superior to etoricoxib with regard to change in VAS score, osteoarthritic severity index, patients' and physicians' global assessment. Change in VAS score for aceclofenac and etoricoxib were 54.41 and $37.12 \mathrm{~mm}$ after 3 weeks and 71 and $53 \mathrm{~mm}$ after 6 weeks of treatment, respectively [42].

\section{Aceclofenac: Safety profile}

GI safety: GI AEs such as dyspepsia, abdominal pain nausea, diarrhoea, flatulence, constipation; vomiting, bleeding and ulcers are an important safety challenge for OA patients receiving NSAIDs
$[63,64]$. Aceclofenac is one of the most potent NSAID which has a COX-1 sparing activity which ensures GI safety as compared to other NSAIDs with an improved therapeutic index [36,63,65,6668]. Aceclofenac was found to be superior to diclofenac in terms of epigastric discomfort, dyspepsia and abdominal pain [18]. In the 12-month safety assessment of marketed medicine (SAMM) study ( $n=10,142$ ), total incidence of adverse events was considerably lesser with aceclofenac than with diclofenac (10.6 versus 15.2\%) [45]. Safety Of non-Steroidal anti-inflammatory drugs (SOS) project, summarized the data available on the risk of GI events from 28 observational studies that included approximately 23.85 million patients. Aceclofenac was associated with the lowest relative risks of upper GI complications among the 16 NSAIDs that included aceclofenac, celecoxib, rofecoxib, sulunic, ibuprofen diclofenac, nimesulide, ketoprofen, meloxicam, tenoxicam, Diflunisal, piroxicam, naproxen, indomethacin, azapropazone, ketorolac [15].

Cardiovascular safety: Based on real world data on almost 10 million NSAIDs users from four European countries, current use of both COX-2 inhibitors and traditional individual NSAIDs are associated with increased risk of heart failure. Odds ratio for the risk of hospital admission due to heart failure associated with current use of NSAID (use in preceding 14 days) is even less with aceclofenac $(1.00,95 \% \mathrm{CI})$ compared to other NSAIDs [44].

Renal safety: A clinical study evaluating the performance of aceclofenac and piroxicam in OA patients found no abnormal variations in the renal function in either treatment group throughout the trial [38].

Hepatic safety: In a review, involving over 6023 patients as regards to hepatic safety profile, aceclofenac was found to be fairly safe. It was found to have an extremely low frequency of druginduced hepatotoxicity which is $0.1 \%$ compared to nimesulide (5.8\%), piroxicam (9.3\%), naproxen (11.1\%), ibuprofen $(14.6 \%)$ and diclofenac (34.1\%). In this review, 6023 liver injury cases were considered [68].

\section{Place of aceclofenac in the management of $\mathrm{OA}$}

With increasing incidence of OA due to prolonged life spans, the management of this condition is a prime concern across medical specialities. There remains a high rate of discontinuation of therapy both by physicians and patients, who remain circumspect regards the adverse effects. While caution has to be advised in patients with significant co-morbidities, a relatively safe NSAID drug suitable for 
most patients is essential. It is unlikely that a very short course of the drug will make a significant difference so patient tolerability also remains a concern. An ideal agent should have good efficacy and a low propensity to cause AEs.

In patients with $\mathrm{OA}$, aceclofenac significantly improved functional capacity and mobility and decreased pain with respect to baseline in large trials of 2 to 6 months' duration. The analgesic and anti-inflammatory efficacy of aceclofenac was usually similar to that of piroxicam, diclofenac, naproxen, and etoricoxib $[42,49,64]$. A meta-analysis demonstrated advantage of aceclofenac in comparison to diclofenac with respect to improvement of knee function in OA patients [64]. In another recent network meta-analysis, aceclofenac had the maximum rankings for improving WOMAC total in OA patients accompanied by naproxen and diclofenac whereas aceclofenac ranked higher on WOMAC function in comparison with etoricoxib [70]. In a pan-European study including Germany, Austria, Belgium and Greece at least 8 in 10 patients with $\mathrm{OA}$, as assessed by both the physician and the patient, were improved or greatly improved in their follow-up visits after treatment with aceclofenac [36]. Aceclofenac is well tolerated and most adverse events are reversible and mild and associated with the GI system. In SAMM study, overall incidence of side-effects was considerably lower with aceclofenac compared to sustained release diclofenac [45]. In addition, in a meta-analysis comprising 3574 patients, significantly higher number of patients treated with aceclofenac remained free from GI symptoms after 3 to 6 months' treatment compared to patients treated with naproxen, piroxicam, diclofenac, indomethacin etc. [71]. Aceclofenac causes significantly lower gastropathy compared with diclofenac [67]. Aceclofenac demonstrated the most favourable therapeutic ratio due to lower potential for gastric damage in comparison with naproxen, indomethacin, and diclofenac [68].

Aceclofenac inhibits inducible COX-2 enzyme and spares COX-1 and causes lower incidence of arterial hypertension, and edema than COX-2 inhibitors [17,48,69]. Odds ratio for the risk of hospital admission due to heart failure for current user of NSAID is even less with aceclofenac compared to Ibuprofen, naproxen, nimesulide, diclofenac, piroxicam, indomethacin, etoricoxib, and ketorolac [44]. In a review, aceclofenac was found to be related with extremely low frequency of drug-induced hepatotoxicity compared to nimesulide, piroxicam, naproxen, ibuprofen and diclofenac [70]. The presence of an efficacious anti-inflammatory drug with a low incidence of adverse effects is of substantial value to both the patient and physician in the management of inflammatory pain. This purpose has been fulfilled with aceclofenac therapy [36].

\section{Conclusion}

Aceclofenac, a phenylacetic acid derivative, is an ideal NSAID for chronic management of osteoarthritis as it has good efficacy and a low propensity to cause adverse effects. It exhibits COX-2 selectivity, inhibits inducible, inflammatory COX-2 enzyme and spares gastroprotective COX-1 enzyme, thus, accounts for superior efficacy and better tolerability profile. In addition to controlling the pain and inflammation in osteoarthritis, aceclofenac also has unique chondroprotective action. This action gives it an edge over other NSAIDs, as this action gives a beneficial influence in the clinical course of Osteoarthritis, in which cartilage synthesis is already reduced. In trials of 6 to 12 month duration, the drug has shown significant reduction in pain with improved functional capacity and mobility in osteoarthritis patients. The analgesic and anti-inflammatory action of aceclofenac is either equivalent or superior to the comparative NSAIDs. It is well tolerated, with most adverse events being mild and reversible and related to the GI system. The favourable tolerability profile of the drug is reflected in reductions in costs associated with managing adverse events relative to other NSAIDs from a healthcare provider's perspective. Since long-term NSAID treatment is indicated for osteoarthritis, the ideal agent should have good efficacy and a low propensity to cause adverse events, and aceclofenac due to preferential inhibition of COX-2 is a good choice.

\section{Conflict of Interest}

Authors, Dr Anu Grover, Mr Amarjit Singh, Dr Indranil Purkait, Dr Apurva Jawdekar and Dr Anil Pareek, are affiliated to Ipca Laboratories Limited and are involved in research studies on aceclofenac.

\section{Bibliography}

1. Chen Di., et al. "Osteoarthritis: toward a comprehensive understanding of pathological mechanism". Bone Research 5 (2017): 16044.

2. Rainbow Roshni., et al. "Inflammation and Joint Tissue Interactions in OA: Implications for Potential Therapeutic Approaches". Arthritis 2012 (2012): 741582.

3. Abramson S B., et al. "Nitric oxide and inflammatory mediators in the perpetuation of osteoarthritis". Current Rheumatology Reports 3.6 (2001): 535-541.

4. Kadam U T., et al. "Clinical comorbidity in patients with osteoarthritis: a case-control study of general practice consulters in England and Wales". Annals of the Rheumatic Diseases 63.4 (2004): 408-414.

5. https://www.who.int/medicines/areas/priority_medicines/ BP6_120steo.pdf 
6. Pal Chandra Prakash., et al. "Epidemiology of knee osteoarthritis in India and related factors". Indian Journal of Orthopaedics 50.5 (2016): 518-522.

7. Kaur Rajvir., et al. "Prevalence of knee osteoarthritis and its determinants in 30-60 years old women of Gurdaspur, Punjab". International Journal of Medical Science and Public Health 7.10 (2018): 825-830.

8. Das AK., et al. "Prevalence and Risk Factors of Knee Osteoarthritis in a Rural Community of Odisha: A Snap Shot Study". JMSCR 06.5 (2018): 15-21.

9. Venkatachalam Jayaseelan., et al. "Prevalence of osteoarthritis of knee joint among adult population in a rural area of Kanchipuram District, Tamil Nadu". Indian Journal of Public Health 62.2 (2018): 117-122.

10. Srinivasan S., et al. "Govindarajan PK. Prevalence of osteoarthritis of the knee joint among elderly population in a rural area". IJBPR 6.11 (2015): 849-851.

11. Ong Kwok Leung., et al. "Arthritis: its prevalence, risk factors, and association with cardiovascular diseases in the United States, 1999 to 2008". Annals of Epidemiology 23.2 (2013): 80-86.

12. Tuominen Ulla., et al. "The effect of co-morbidities on healthrelated quality of life in patients placed on the waiting list for total joint replacement". Health and Quality of Life Outcomes 5.16 (2007).

13. Sancheti Parag., et al. "India-Based Knee Osteoarthritis Evaluation (iKare): A Multi-Centre Cross-Sectional Study on the Management of Knee Pain and Early Osteoarthritis in India”. Clinics in Orthopedic Surgery 9.3 (2017): 286-294.

14. Firdose S., et al. "Cost of Illness Analysis of Knee Osteoarthritis in a Tertiary Care Hospital". Journal of Young Pharmacists 10.3 (2018): 322-325.

15. Castellsague Jordi., et al. "Individual NSAIDs and upper gastrointestinal complications: a systematic review and meta-analysis of observational studies (the SOS project)". Drug Safety 35,12 (2012): 1127-1146.

16. Pelletier Jean-Pierre., et al. "Efficacy and safety of oral NSAIDs and analgesics in the management of osteoarthritis: Evidence from real-life setting trials and surveys". Seminars in Arthritis and Rheumatism 45.4 (2016): S22-27.

17. Raber Anna., et al. "Incidence of spontaneous notifications of adverse reactions with aceclofenac, meloxicam, and rofecoxib during the first year after marketing in the United Kingdom". Therapeutics and Clinical Risk Management 3.2 (2007): 225230.

18. Pareek A., et al. "Efficacy and safety of aceclofenac in the treatment of osteoarthritis: a randomized double-blind comparative clinical trial versus diclofenac - an Indian experience". Current Medical Research and Opinion 22.5 (2006): 977-988.
19. Dingle J T. "The effect of nonsteroidal antiinflammatory drugs on human articular cartilage glycosaminoglycan synthesis". Osteoarthritis and Cartilage 7.3 (1999): 313-314.

20. Dingle J T. "The effects of NSAID on the matrix of human articular cartilages". Zeitschrift fur Rheumatologie 58.3 (1999): 125-129.

21. Dingle JT and Parker M. "NSAID Stimulation of Human Cartilage Matrix Synthesis. A Study of the Mechanism of Action of Aceclofenac". Clinical Drug Investigation 14.5 (1997): 353-362.

22. Cutolo Maurizio., et al. "Commentary on recent therapeutic guidelines for osteoarthritis". Seminars in Arthritis and Rheumatism 44.6 (2015): 611-617.

23. Stanos Steven. "Osteoarthritis guidelines: a progressive role for topical NSAIDs". The Journal of the American Osteopathic Association 113.2 (2013): 123-127.

24. Bruyère Olivier., et al. "A consensus statement on the European Society for Clinical and Economic Aspects of Osteoporosis and Osteoarthritis (ESCEO) algorithm for the management of knee osteoarthritis-From evidence-based medicine to the real-life setting". Seminars in Arthritis and Rheumatism 45.4 (2016): S3-11.

25. McAlindon T E., et al. "OARSI guidelines for the non-surgical management of knee osteoarthritis". Osteoarthritis and Cartilage 22.3 (2014): 363-388.

26. NICE: National Institute for Health and Care Excellence. "Osteoarthritis: care and management in adults". NICE Guidelines (2014).

27. Hochberg Marc C., et al. "American College of Rheumatology 2012 recommendations for the use of nonpharmacologic and pharmacologic therapies in osteoarthritis of the hand, hip, and knee". Arthritis Care and Research 64.4 (2012): 465-474.

28. The Royal Australian College of General Practitioners. Guideline for the management of knee and hip osteoarthritis. 2nd ed East Melbourne, Vic: RACGP (2018).

29. Jordan K M., et al. "EULAR Recommendations 2003: an evidence based approach to the management of knee osteoarthritis: Report of a Task Force of the Standing Committee for International Clinical Studies Including Therapeutic Trials (ESCISIT)". Annals of the Rheumatic Diseases 62.12 (2003): 11451155.

30. European Medicines Agency. "Guideline on clinical investigation of medicinal products used in the treatment of osteoarthritis" (2010).

31. Dammann H G. "Die bevorzugte COX-2-Hemmung: ihre klinische Relevanz für die gastrointestinale NSAR-Toxizität" [Preferential COX-2 inhibition: its clinical relevance for gastrointestinal non-steroidal anti-inflammatory rheumatic drug toxicity]. Zeitschrift fur Gastroenterologie 37.1 (1999): 45-58. 
32. Topol Eric J. "Failing the public health--rofecoxib, Merck, and the FDA". The New England Journal of Medicine 351.17 (2004): 1707-1709.

33. Chou R., et al. "Analgesics for osteoarthritis: an update of the 2006 comparative effectiveness review". (2011).

34. Haveles, Elena Bablenis. Applied Pharmacology for the Dental Hygienist-E-Book. Elsevier Health Sciences, (2014).

35. Grosser T. "Non-steroidal anti-inflammatory drugs and coxibs". In: Burton ME, ed. Applied pharmacokinetics and pharmacodynamics: principles of therapeutic drug monitoring. 4th ed. Lippincott Williams and Wilkins (2006): 752-780.

36. Lemmel Ernst-Martin., et al. "Patient and physician satisfaction with aceclofenac: results of the European Observational Cohort Study (experience with aceclofenac for inflammatory pain in daily practice). Aceclofenac is the treatment of choice for patients and physicians in the management of inflammatory pain". Current Medical Research and Opinion 18.3 (2002): 146-153.

37. Ward D E., et al. "Comparison of aceclofenac with diclofenac in the treatment of osteoarthritis". Clinical Rheumatology 14.6 (1995): 656-662.

38. Peréz Busquier M., et al. "Comparison of aceclofenac with piroxicam in the treatment of osteoarthritis". Clinical Rheumatology 16.2 (1997): 154-159.

39. Torri G., et al. "Aceclofenac versus piroxicam in the management of osteoarthritis of the knee: a double-blind controlled study". Current Therapeutic Research 55.5 (1994): 576-583.

40. Kornasoff D., et al. "Aceclofenac is a well-tolerated alternative to naproxen in the treatment of osteoarthritis". Clinical Rheumatology 16.1 (1997): 32-38.

41. Pareek Anil., et al. "A randomized, multicentric, comparative evaluation of aceclofenac-paracetamol combination with aceclofenac alone in Indian patients with osteoarthritis flareup". Expert Opinion on Pharmacotherapy 10,5 (2009): 727 735.

42. Waraich Harsimrat S., et al. "A comparative study to assess the safety and efficacy of etoricoxib versus aceclofenac in osteoarthritis". International Journal of Basic and Clinical Pharmacology 7.10 (2018): 2010.

43. Klair Jagpal Singh. "A Comparative Study of Efficacy and Tolerability of Ibuprofen vs. Aceclofenac in Osteoarthritis of Knee Joint". Annals of Medicine and Healthcare Research (2009): 236-280.
44. Arfè Andrea., et al. "Non-steroidal anti-inflammatory drugs and risk of heart failure in four European countries: nested case-control study". BMJ (Clinical research ed.) (2016): 354 i4857.

45. Huskisson E C., et al. "A large prospective open-label, multicentre SAMM study, comparing the safety of aceclofenac with diclofenac in patients with rheumatic disease". European Journal of Rheumatology and Inflammation 17.1 (2000): 1-7.

46. Brogden R N and L R Wiseman. "Aceclofenac. A review of its pharmacodynamic properties and therapeutic potential in the treatment of rheumatic disorders and in pain management". Drugs 52.1 (1996): 113-124.

47. Arslan S., et al. "A nonsteroidal antiinflammatory drug: aceclofenac". FABA Journal of Pharmaceutical Sciences 35.2 (2010): 105-118.

48. Hinz Burkhard., et al. "Aceclofenac spares cyclooxygenase 1 as a result of limited but sustained biotransformation to diclofenac". Clinical Pharmacology and Therapeutics 74.3 (2003): 222-235.

49. Dooley M., et al. "Aceclofenac: a reappraisal of its use in the management of pain and rheumatic disease". Drugs 61.9 (2001): 1351-1378.

50. Hinz Burkhard., et al. "Aceclofenac spares cyclooxygenase 1 as a result of limited but sustained biotransformation to diclofenac". Clinical Pharmacology and Therapeutics 74.3 (2003): 222-235.

51. Alvarez-Soria M A., et al. "Long-term NSAID treatment directly decreases COX-2 and mPGES-1 production in the articular cartilage of patients with osteoarthritis". Osteoarthritis and Cartilage 16,12 (2008): 1484-1493.

52. Henrotin Y., et al. "In vitro effects of aceclofenac and its metabolites on the production by chondrocytes of inflammatory mediators". Inflammation Research: Official Journal of the European Histamine Research Society 50.8 (2001): 391-399.

53. Martel-Pelletier., et al. "Effects of aceclofenac and diclofenac on synovial inflammatory factors in human osteoarthritis". Clinical Drug Investigation 14.3 (1997): 226-232.

54. Maneiro E., et al. "Aceclofenac increases the synthesis of interleukin 1 receptor antagonist and decreases the production of nitric oxide in human articular chondrocytes". The Journal of Rheumatology 28.12 (2001): 2692-2699. 
55. Yamazaki R., et al. "A major metabolite of aceclofenac, 4'-hydroxy aceclofenac, suppresses the production of interstitial pro-collagenase/proMMP-1 and pro-stromelysin-1/proMMP-3 by human rheumatoid synovial cells". Inflammation Research: Official Journal of the European Histamine Research Society 49.3 (2000): 133-138.

56. Cecchettin M., et al. "Therapeutic efficacy of aceclofenac and diclofenac in acute knee arthroses-a study of e2-prostaglandin levels in synovial-fluid and in serum". Clinical Trials Journal 25.2 (1988): 144-151.

57. González-Alvaro I., et al. "Aceclofenac, a new nonsteroidal antiinflammatory drug, decreases the expression and function of some adhesion molecules on human neutrophils". The Journal of Rheumatology 23.4 (1996): 723-729.

58. Pelletier J P. "The influence of tissue cross-talking on OA progression: role of nonsteroidal antiinflammatory drugs". Osteoarthritis and Cartilage 7.4 (1999): 374-376.

59. Blot L., et al. "Effects of diclofenac, aceclofenac and meloxicam on the metabolism of proteoglycans and hyaluronan in osteoarthritic human cartilage". British Journal of Pharmacology 131.7 (2000): 1413-1421.

60. Patil Pramod Reddy., et al. "A comparative study of efficacy and safety of diclofenac and aceclofenac in the treatment of osteoarthritis patients". Journal of Drug Delivery and Therapeutics 2.4 (2012).

61. Ali Shaik Mohammad., et al. "Comparative study of safety efficacy and tolerability of aceclofenac verses diclofenac in osteoarthritis patients attending a secondary care hospital in anantapuramu". Indo American Journal of Pharmaceutical Sciences 4.5 (2017): 1260-1277.

62. Pareek Anil., et al. "Efficacy and safety of aceclofenac-cr and aceclofenac in the treatment of knee osteoarthritis: a 6-week, comparative, randomized, multicentric, double-blind study". The Journal of Pain: Official Journal of the American Pain Society 12.5 (2011): 546-553.

63. Legrand Erik. "Aceclofenac in the management of inflammatory pain". Expert Opinion on Pharmacotherapy 5.6 (2004): 1347-1357.

64. Patel Parvati B and Tejas K Patel. "Efficacy and safety of aceclofenac in osteoarthritis: A meta-analysis of randomized controlled trials". European Journal of Rheumatology 4.1 (2017): 11-18.
65. Pareek Anil and Nitin Chandurkar. "Comparison of gastrointestinal safety and tolerability of aceclofenac with diclofenac: a multicenter, randomized, double-blind study in patients with knee osteoarthritis". Current Medical Research and Opinion 29.7 (2013): 849-859.

66. Ibáñez Luisa., et al. "Proton pump inhibitors and risk of upper gastrointestinal bleeding in NSAID users". The American Journal of Gastroenterology 103.10 (2008): 2658-2659.

67. Yanagawa Akira., et al. "Endoscopic evaluation of aceclofenacinduced gastroduodenal mucosal damage: a double-blind comparison with sodium diclofenac and placebo". Japanese Journal of Rheumatology 8.3 (1998): 249-259.

68. Grau M., et al. "Pharmacology of the potent new non-steroidal anti-inflammatory agent aceclofenac". Arzneimittel-Forschung 41.12 (1991): 1265-1276.

69. Agúndez José Ag., et al. "Assessment of nonsteroidal anti-inflammatory drug-induced hepatotoxicity". Expert Opinion on Drug Metabolism and Toxicology 7.7 (2011): 817-828.

70. Jung Sun-Young., et al. "Comparative effectiveness of oral pharmacologic interventions for knee osteoarthritis: A network meta-analysis". Modern Rheumatology 28.6 (2018): 10211028.

71. Peris F., et al. "Treatment compliance and safety of aceclofenac versus standard NSAIDs in patients with common arthritic disorders: a meta-analysis". European Journal of Rheumatology and Inflammation (English edition) 16.1 (1996): 37-45.

\section{Assets from publication with us}

- Prompt Acknowledgement after receiving the article

- Thorough Double blinded peer review

- Rapid Publication

- Issue of Publication Certificate

- High visibility of your Published work

Website: https://www.actascientific.com/

Submit Article: https://www.actascientific.com/submission.php Email us: editor@actascientific.com

Contact us: +919182824667 